\title{
Isolation and Characterization of the RNA of Membrane-bound Ribosomes in Dictyostelium discoideum
}

\author{
By LILLY Y. W. BOURGUIGNON* AND E. R. KATZ \\ Department of Biology, State University of New York at Stony \\ Brook, Stony Brook, New York 11794, U.S.A.
}

(Received 31 August 1977; revised 12 December 1977)

\begin{abstract}
The RNA of membrane-bound ribosomes, isolated from Dictyostelium discoideum, represented 13 to $16 \%$ of the total ribosomal RNA (rRNA) present throughout growth and development. Membrane-bound ribosomes were released by treatment with sodium deoxycholate and Brij 58. There were no obvious differences in size and base composition between RNAs derived from membrane-bound or free ribosomes. The $17 \mathrm{~S}$ membrane-bound rRNA and free rRNAs appeared to have similar methyl contents. However, the $25 \mathrm{~S}$ membranebound rRNA contained about 16 to $20 \%$ fewer methyl groups than the $17 \mathrm{~S}$ membranebound rRNA and free rRNAs. Free rRNAs turned over rapidly during early development but not during the disaggregation and reaggregation processes. Membrane-bound rRNAs showed very little turnover during the early stages of morphogenesis, but showed rapid turnover during the late stages of development; this class of rRNAs did not turn over during early stages of reaggregation but turned over rapidly during later stages of reaggregation.
\end{abstract}

\section{INTRODUCTION}

The cellular slime mould, Dictyostelium discoideum, has been used as a model organism for the study of morphogenesis and differentiation (Bonner, 1967; Sussman \& Sussman, 1969; Loomis, 1975). The life cycle of D. discoideum has two phases, one of growth and multiplication and one of morphogenesis and differentiation. This clear separation of growth and development makes the organism very suitable for studying cellular regulation and biosynthesis.

Eukaryotic cells contain two different classes of ribosomes, one free in the cytoplasmic matrix and the other associated with the membranes of the endoplasmic reticulum. Recently, it has been suggested that there are functional differences between membranebound and free ribosomes. It has been reported that membrane-bound ribosomes in rat hepatic cells synthesize serum proteins whilst free ribosomes synthesize non-serum proteins (Takagi \& Ogata, 1968; Takagi, Tanaka \& Ogata, 1969). Using in vitro systems of HeLa cells or HeLa cells infected with poliovirus, Roumaintzeff, Summers \& Maizel (1971) showed that membrane-bound polysomes have much greater protein synthesizing activity than free polysomes. The free ribosomes of $D$. discoideum have been studied extensively. They are of the eukaryotic $80 \mathrm{~S}$ type and can be dissociated into the two subunits of $60 \mathrm{~S}$ and $40 \mathrm{~S}$; the $60 \mathrm{~S}$ and $40 \mathrm{~S}$ subunits contain RNAs sedimenting at $25 \mathrm{~S}$ and $17 \mathrm{~S}$ respectively (Ceccarini \& Maggio, 1968). Cocucci \& Sussman (1970) showed that in D. discoideum the free ribosomal RNA synthesized during the growth or multiplication stage is largely degraded during morphogenesis and replaced by newly synthesized RNA. They suggested

\footnotetext{
* Present address: Department of Biology, Wayne State University, Detroit, Michigan 48202, U.S.A.
} 
that translational control may play an important role in regulating cellular differentiation. In this work, we attempted to determine whether membrane-bound ribosomes and their RNAs play a role in the differentiation of the cellular slime mould.

\section{METHODS}

Culture and medium. Dictyostelium discoideum, strain AX-3 (obtained from wild-type NC-4 by W. F. Loomis, $\mathrm{Jr}$ ) was used in all experiments. Strain AX-3 was grown axenically in HL-5 liquid medium (Cocucci \& Sussman, 1970), which contained (per ml): glucose, $16 \mathrm{mg}$; yeast extract, $7 \mathrm{mg}$; proteose peptone, $14 \mathrm{mg}$; $\mathrm{Na}_{2} \mathrm{HPO}_{4} .7 \mathrm{H}_{2} \mathrm{O}, 0.95 \mathrm{mg} ; \mathrm{KH}_{2} \mathrm{PO}_{4}, 0.5 \mathrm{mg}$.

Buffers. Lower Pad (LP) solution contained: sodium potassium phosphate, $0.04 \mathrm{M}, \mathrm{pH} 6.5 ; \mathrm{KCl}, 1.5 \mathrm{mg}$ $\mathrm{ml}^{-1} ; \mathrm{MgCl}_{2}, 9.5 \mathrm{mg} \mathrm{ml}^{-1}$; streptomycin sulphate, $0.5 \mathrm{mg} \mathrm{ml}^{-1}$. Tris/KCl/ $\mathrm{MgCl}_{2}$ (TKM) buffer contained: Tris/HCl buffer, $0.01 \mathrm{~m}, \mathrm{pH} 7.5 ; \mathrm{KCl}, 0.01 \mathrm{~m} ; \mathrm{MgCl}_{2}, 0.15 \mathrm{~mm}$. Tris/LiCl/urea (TLU) buffer contained: Tris/HCl buffer, $0.01 \mathrm{~m}, \mathrm{pH} 7.5 ; \mathrm{LiCl}, 4 \mathrm{~m}$; urea, 8 м. Sodium dodecyl sulphate (SDS) buffer contained: Tris/ $\mathrm{HCl}$ buffer, $0.01 \mathrm{M}, \mathrm{pH} 7.5 ; \mathrm{NaCl}, 0.1 \mathrm{~m}$; EDTA, $0.01 \mathrm{~m}$; sodium dodecyl sulphate, $0.5 \%(\mathrm{w} / \mathrm{v})$. Tris $/ \mathrm{KCl} /$ $\mathrm{MgCl}_{2}$ /sucrose (TKMS) buffer contained: Tris/ $\mathrm{HCl}$ buffer, $0.01 \mathrm{M}, \mathrm{pH} 7.5 ; \mathrm{KCl}, 0.01 \mathrm{M} ; \mathrm{MgCl}_{2}, 0.15 \mathrm{~mm}$; sucrose, $6 \%(\mathrm{w} / \mathrm{v})$.

Conditions for growth and morphogenesis. Strain AX-3 was grown with a $10 \mathrm{~h}$ doubling time in sterile HL-5 liquid medium at $22^{\circ} \mathrm{C}$ with constant shaking. To obtain synchronous morphogenesis, cells were harvested from liquid medium by centrifugation $(270 \mathrm{~g}, 5 \mathrm{~min})$ and then placed on Whatman 50 filters supported by pads saturated with LP solution (Sussman, 1966). Strain AX-3 showed a normal morphogenetic sequence and completed development in $28 \mathrm{~h}$.

Preparation of membrane-bound and free ribosomes. A modification of the method of Attardi \& Attardi (1969) was used to obtain membrane-bound ribosomes. Labelled cells were lysed by sonication for $20 \mathrm{~s}$ with a Branson Sonic Power Sonicator. Unbroken cells and nuclei were removed by centrifugation $(480 \mathrm{~g}$, $5 \mathrm{~min}$ ). The supernatant was recentrifuged at $480 \mathrm{~g}$ several times, all pellets being discarded, and was then centrifuged at $17300 \mathrm{~g}$ for $20 \mathrm{~min}$. The pellet from this centrifugation contained membrane-bound ribosomes. The $17300 \mathrm{~g}$ supernatant was then centrifuged at $105000 \mathrm{~g}$ for $3 \mathrm{~h}$; the resulting pellet contained free polysomes and $80 \mathrm{~S}$ ribosomes.

Electron microscopic examination of membrane fraction. The membrane fraction $(17300 \mathrm{~g}$ pellet) was fixed in TKMS buffer containing glutaraldehyde $(2.4 \%, v / v)$ for $1 \mathrm{~h}$, then washed by adding and pipetting off TKMS buffer and subsequently fixed with $1 \%(\mathrm{w} / \mathrm{v})$ osmium tetroxide in TKMS buffer for $1 \mathrm{~h}$. The fixed membrane fraction was dehydrated by a series of washes in acetone $(30,50,70,95$ and $100 \%, \mathrm{v} / \mathrm{v})$, before embedding in Epon 812. Thin sections of membrane preparation were cut with a Sorvall ultramicrotome and stained with uranyl acetate and lead citrate. Specimens were examined with a Siemens 101 electron microscope.

Analysis of membrane-bound and free ribosomes. Radioactively labelled (see below) membrane-bound or free ribosome pellets were resuspended in $0.5 \mathrm{ml}$ TKM buffer and layered on top of a discontinuous sucrose gradient (Attardi, Craviot \& Attardi, 1969) comprising a continuous 15 to $30 \%(\mathrm{w} / \mathrm{v})$ sucrose gradient in TKM buffer $(36 \mathrm{ml})$ over $65 \%(\mathrm{w} / \mathrm{v})$ sucrose $(4 \mathrm{ml})$. After centrifugation in a Spinco SW27 rotor $\left(80000 \mathrm{~g}, 100 \mathrm{~min}, 4^{\circ} \mathrm{C}\right)$ the gradients were fractionated by inserting a needle into the bottom of the gradient and pumping out the liquid. The absorbance at $260 \mathrm{~nm}$ of each fraction was measured using a Gilford spectrophotometer with a flow cell. The radioactivity of each fraction was determined as described below.

Isolation and analysis of RNA from membrane-bound and free ribosomes. Ribosomal RNA (rRNA) was isolated by the method of Leboy, Cox \& Flaks (1964) with modifications. Ribosomal RNAs were freed from ribosomal proteins by adding TLU buffer to the membrane-bound ribosomes and free ribosome fractions. After mixing, suspensions were left at $0{ }^{\circ} \mathrm{C}$ overnight and then 2 vol. $95 \%(\mathrm{v} / \mathrm{v})$ ethanol was added to precipitate the rRNAs. The precipitated rRNAs were separated by centrifuging $(100000 \mathrm{~g}, 120 \mathrm{~min})$, resuspended in $1 \mathrm{ml}$ SDS buffer and layered on to a sucrose gradient (15 to $30 \%, \mathrm{w} / \mathrm{v}$ ) in SDS buffer. The gradient was centrifuged in an SW27 rotor $\left(101000 \mathrm{~g}, 20^{\circ} \mathrm{C}, 16 \mathrm{~h}\right)$. After centrifugation, gradients were fractionated and the absorbance at $260 \mathrm{~nm}$ and radioactivity of fractions were measured as described previously. In all experiments, $25 \mathrm{~S}$ rRNA is defined as the pooled $A_{260}$ units peak and/or radioactivity in fractions 8 to 10 , and $17 \mathrm{~S}$ rRNA is defined as the pooled $A_{260}$ units peak and/or radioactivity in fractions 13 to 15 (see Fig. 2).

Methylation conditions. [methyl- $\left.{ }^{3} \mathrm{H}\right]$ Methionine $\left(0 \cdot 1 \mathrm{mCi}, 2 \cdot 3 \mathrm{Ci} \mathrm{mmol}^{-1}\right.$; Schwarz Mann, Orangeburg, New Jersey, U.S.A.) was added to $25 \mathrm{ml} \mathrm{HL}-5$ liquid medium inoculated with strain AX-3. After two generations of growth, cells were harvested and ribosomes and rRNAs were isolated. 
Base composition analysis of RNA of membrane-bound and free ribosomes throughout growth and development. RNAs of membrane-bound and free ribosomes from growth and development stages were isolated according to the procedures described above. About $2 A_{260}$ units of isolated membrane-bound and free rRNAs were digested by $10 \mu 1 \mathrm{~T}_{2}$ RNAase ( 5 units) in $20 \mu \mathrm{l} 20 \mathrm{~mm}$-ammonium acetate (pH 4.5) buffer for $4 \mathrm{~h}$ at $37^{\circ} \mathrm{C}$ (Rushizky \& Sober, 1963). Digestion mixtures were then spotted on silica gel or cellulose thin-layer chromatography plates, and developed in one dimension with isobutyric acid/1 M- $\mathrm{NH}_{4} \mathrm{OH}$ (5:3, by vol.; solvent 1) (Tamm et al., 1953) and in the other with 2-propanol $/ \mathrm{HCl} / \mathrm{H}_{2} \mathrm{O}(65: 16 \cdot 7: 18 \cdot 3$, by vol.; solvent 2) (Wyatt, 1951). Separated nucleotide spots were detected with ultraviolet light (240 to $260 \mathrm{~nm}$ ) and eluted with $1 \mathrm{ml} 0 \cdot 1 \mathrm{M}-\mathrm{HCl}$. The absorption spectrum and absorbance units of individual eluted spots were measured with a Cary (model 15) spectrophotometer.

Turnover of membrane-bound $r R A$ during morphogenesis. Strain AX-3 was grown in HL-5 liquid medium $(150 \mathrm{ml})$ containing [6- $\left.{ }^{3} \mathrm{H}\right]$ uracil $\left(0 \cdot 3 \mathrm{mCi}, 12 \mathrm{mCi}^{2} \mathrm{~mol}^{-1}\right.$; New England Nuclear). After two generations ( 20 to $24 \mathrm{~h}$ ), cells were harvested and washed with LP solution two or three times. In order to chase the radioactive label during morphogenesis, the labelled amoebae were put on Whatman 50 filters which, in turn, were placed on Millipore pads saturated with LP solution containing $10^{-3} \mathrm{M}$ unlabelled uracil. Cells were resuspended by immersing the filter in TKM buffer, and vigorously mixing with a vortex mixer. At intervals during the chase period, cells were collected and the amount of label in free and membrane-bound rRNA was determined.

Conditions for disaggregation and reaggregation of pseudoplasmodia. Aggregates at about the $8 \mathrm{~h}$ developmental stage were labelled with $\left[6{ }^{3} \mathrm{H}\right]$ uracil $\left(12 \mathrm{mCi} \mu \mathrm{mol}^{-1}\right)$ for $2 \mathrm{~h}$ by placing a Whatman 50 filter containing the cells directly on top of and in contact with a second Whatman 50 filter impregnated with the labelled solution. Labelled cells were resuspended in TKM buffer by agitating on a vortex mixer for 2 min and examined with a light microscope to ascertain the degree of disaggregation. Agitation was continued until only single cells remained. To resume the developmental process, these cells were then placed on filters saturated with LP solution containing $10^{-3} \mathrm{M}$ unlabelled uracil. At intervals after placing the cells back on filters, RNAs from membrane-bound and free ribosomes were isolated and the relative specific radioactivities (as percentages of the initial values) of these two types of rRNAs were determined. The specific radioactivity of rRNA was expressed as the trichloroacetic acid-insoluble radioactivity (c.p.m.) per mg RNA or protein.

Measurement of radioactivity. To each fraction of the gradient was added $1 \mathrm{ml}$ bovine serum albumin $\left(200 \mu \mathrm{g} \mathrm{ml}^{-1}\right)$ as carrier, and then 2 vol. cold $(15 \%, \mathrm{w} / \mathrm{v})$ trichloroacetic acid. The precipitates were collected on glass-fibre filters, and the filters were placed in scintillation fluid [2,5-diphenyloxazole (PPO) and 2,2'-pphenylene-bis-(5-phenyloxazole) (POPOP) in toluene] and counted in a Packard Tri-Carb liquid scintillation counter.

\section{RESULTS}

\section{Isolation and identification of membrane-bound ribosomes and free ribosomes}

Membrane-bound ribosomes and free ribosomes can be separately isolated by differential centrifugation (Sabatini, Tashiro \& Palade, 1966). Sedimentation on a discontinuous sucrose gradient (Attardi \& Attardi, 1969) was used to confirm that the $17300 \mathrm{~g}$ and $105000 \mathrm{~g}$ pellets were membrane-bound and free ribosomes, respectively. After centrifugation $(80000 \mathrm{~g}, 100 \mathrm{~min})$ the material in the $105000 \mathrm{~g}$ pellet remained at the top of the gradient while $80 \%$ of the material in the $17300 \mathrm{~g}$ pellet accumulated at the $65 \%$ sucrose shelf (Fig. $1 a, b$ ). The material sedimenting to the shelf was assumed to be tightly bound to membranes (Attardi \& Attardi, 1967). This rapidly sedimenting RNA was dissociated from membranes by treatment with $1 \%(\mathrm{w} / \mathrm{v})$ sodium deoxycholate and $1 \%(\mathrm{w} / \mathrm{v})$ Brij 58 (Fig. 1c). When centrifuged on SDS sucrose gradients, the RNA isolated from the membrane-bound ribosomes showed sedimentation values that appeared to be identical to those from free ribosomes (Fig. 2). The $25 \mathrm{~S}$ and $17 \mathrm{~S}$ rRNAs were clearly separated into two peaks.

\section{Electron microscopic examination of membrane fraction}

The membrane fraction $(17300 \mathrm{~g}$ pellet) was examined to determine whether or not it contained endoplasmic reticulum (ER) associated ribosomes, the so-called rough ER. The membrane fraction isolated from strain AX-3 after $12 \mathrm{~h}$ in developmental stage was prepared as described in Methods. Electron micrographs showed that the $17300 \mathrm{~g}$ pellet 


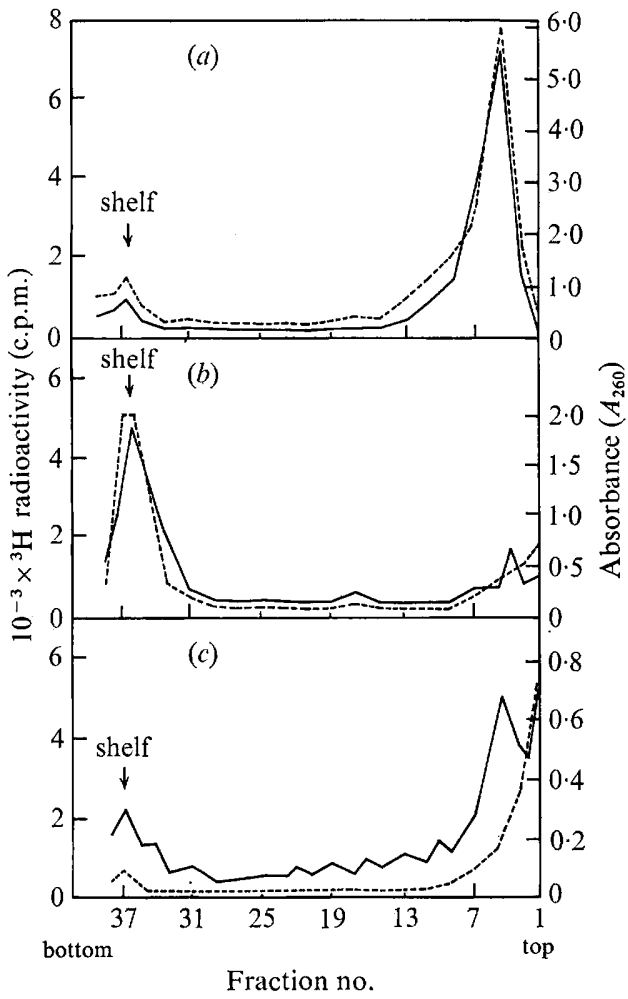

Fig. 1

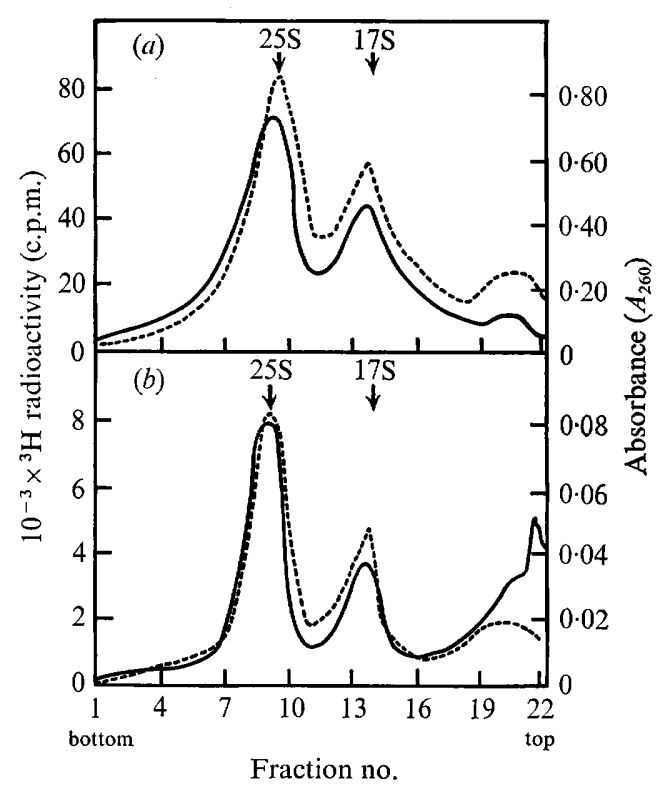

Fig. 2

Fig. 1. Sucrose gradient centrifugation of membrane-bound and free ribosomes of $D$. discoideum. $\left[6^{3} \mathrm{H}\right]$ Uracil-labelled free and membrane-bound ribosomes (see Methods) were centrifuged through a $36 \mathrm{ml}$ linear sucrose gradient ( 15 to $30 \%$ w/v) layered over a $4 \mathrm{ml}$ shelf of $65 \%(\mathrm{w} / \mathrm{v})$ sucrose for $100 \mathrm{~min}$ at $80000 \mathrm{~g}$ and $4{ }^{\circ} \mathrm{C}$ using an SW27 rotor. (a) Free ribosomes; $(b)$ membranebound ribosomes before treatment with sodium deoxycholate and Brij $58 ;(c)$ membrane-bound ribosomes after treatment with $1 \%$ sodium deoxycholate and $1 \%$ Brij 58 . —, Absorbance $\left(A_{260}\right)$; --- ${ }^{3} \mathrm{H}$ radioactivity.

Fig. 2. Sucrose gradient centrifugation of RNAs from free and membrane-bound ribosomes. $\left[6^{-3} \mathrm{H}\right]$ Uracil-labelled RNAs from free and membrane-bound ribosomes (see Methods) were centrifuged through a $36 \mathrm{ml}$ linear sucrose gradient $(15$ to $30 \%$, w/v) in SDS buffer $(16 \mathrm{~h}$, $101000 \mathrm{~g}, 20^{\circ} \mathrm{C}$ ) using an SW27 rotor. (a) Free rRNAs; (b) membrane-bound rRNAs. $\longrightarrow$, Absorbance $\left(A_{260}\right) ;---,{ }^{3} \mathrm{H}$ radioactivity.

consisted primarily of ribosomes attached to membrane material (probably rough ER). Although there was some broken mitochondrial contamination in this membrane fraction, most of the pellet fraction consisted of membranes with attached ribosomal-sized particles (Fig. 3).

\section{Methylation of RNA of membrane-bound and free ribosomes}

Since the methyl content of the RNA from membrane-bound and free ribosomes is extremely variable in different tissues or cell types (Hulse \& Wettstein, 1972; Murthy, 1972), it was of interest to compare the methylation of RNA in membrane-bound and free ribosomes in the cellular slime mould. The amount of methylation was determined by long-term labelling with $\left[\right.$ methyl - $\left.^{3} \mathrm{H}\right]$ methionine (see Methods). In vegetative amoebae, the 17S RNA from membrane-bound and free ribosomes appeared to be methylated to the same degree (Table 1). However, the 25S RNA from membrane-bound ribosomes appeared to contain about 16 to $20 \%$ fewer methyl groups than the corresponding $25 \mathrm{~S}$ RNA from free ribosomes. 


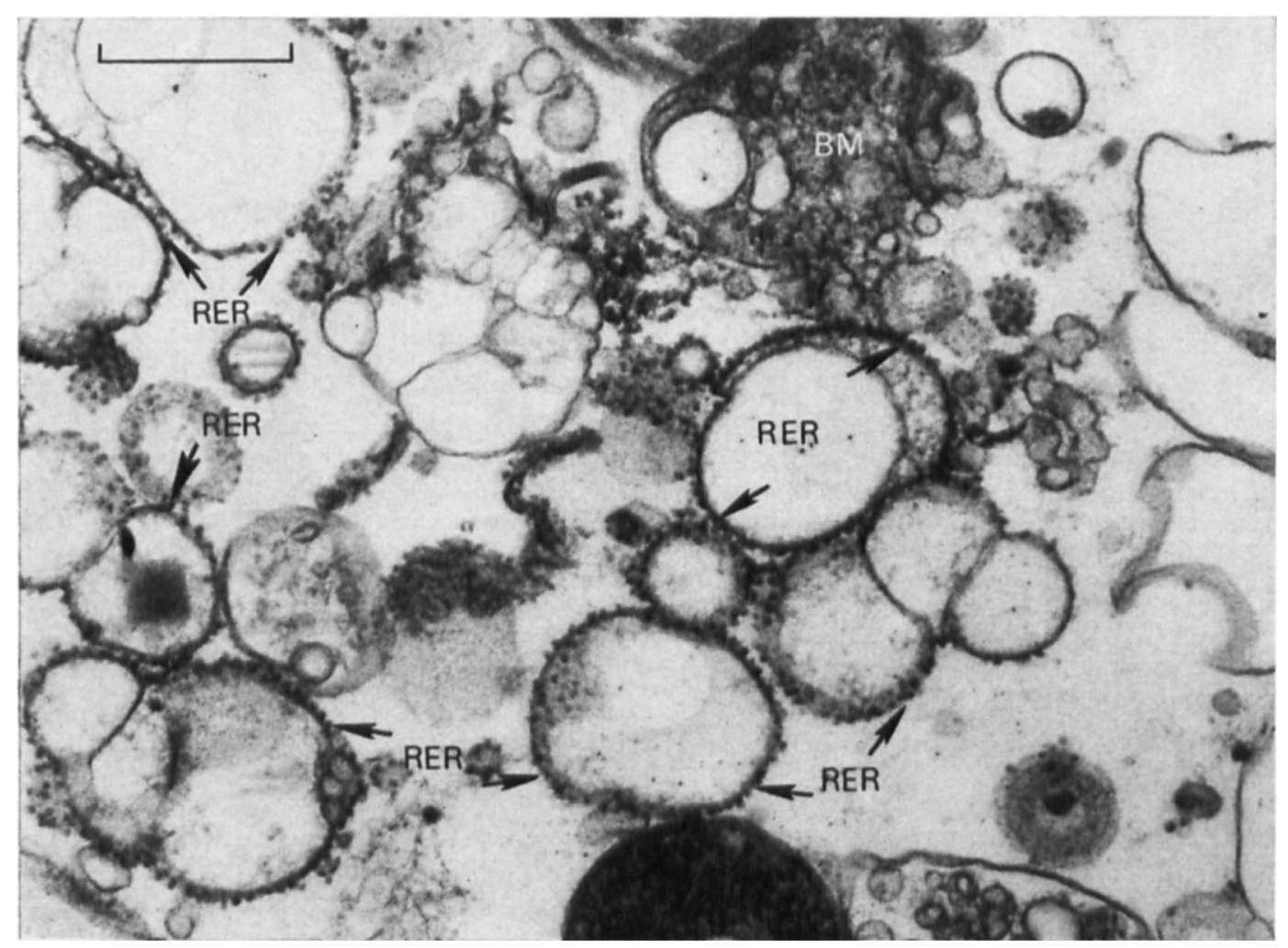

Fig. 3. Electron micrograph of the membrane fraction $(17300 \mathrm{~g}$ pellet) isolated from strain $\mathrm{AX}-3$ in the developmental stage ( $12 \mathrm{~h}$ on filter). BM, Broken mitochondria; RER, rough endoplasmic reticulum, i.e. ribosome-attached membrane vesicles. Bar marker represents $1 \mu \mathrm{m}$.

Table 1. Methylation of RNA isolated from membrane-bound and free ribosomes of $D$. discoideum

Vegetative amoebae were labelled with $\left[\right.$ methyl $\left.{ }^{3} \mathrm{H}\right]$ methionine $\left(0 \cdot 1 \mathrm{mCi}, 2 \cdot 3 \mathrm{Ci} \mathrm{mmol}^{-1}\right)$ for two generations. RNAs from membrane-bound and free ribosomes were isolated as described in Methods.

\begin{tabular}{|c|c|c|c|}
\hline & $\begin{array}{c}{ }^{3} \mathrm{H} \text { radioactivity } \\
\text { in RNA (c.p.m.) } \\
\text { (A) }\end{array}$ & $\begin{array}{l}\text { Absorbance } \\
\left(A_{260} / 10^{8} \text { cells }\right) \\
\text { (B) }\end{array}$ & $10^{-4} \times \mathrm{A} / \mathrm{B}$ \\
\hline \multicolumn{4}{|l|}{ Free rRNA } \\
\hline $25 \mathrm{~S}$ & 30997 & $1 \cdot 590$ & $1.95 \pm 0.06$ \\
\hline $17 \mathrm{~S}$ & 15326 & $0 \cdot 790$ & $1.94 \pm 0.04$ \\
\hline $25 \mathrm{~S}+17 \mathrm{~S}$ & 46323 & $2 \cdot 380$ & $1.95 \pm 0.05$ \\
\hline \multicolumn{4}{|c|}{ Membrane-bound rRNA } \\
\hline $25 \mathrm{~S}$ & 3965 & $0 \cdot 243$ & $1.63 \pm 0.07$ \\
\hline $17 \mathrm{~S}$ & 2463 & $0 \cdot 123$ & $2.00 \pm 0.04$ \\
\hline $25 S+17 S$ & 6428 & $0 \cdot 366$ & $1.76 \pm 0.06$ \\
\hline
\end{tabular}

Base composition analysis of RNA of membrane-bound and free ribosomes throughout growth and development

Membrane-bound and free rRNAs from different stages in growth and development were digested by $T_{2}$ RNAase and nucleotides were separated by two-dimensional thin-layer chromatography. Only the four major nucleotides of rRNAs were identified - by their $R_{F}$ values (solvent 1: AMP, 0.724; CMP, 0.644; GMP, 0.457; UMP, 0.490; solvent 2: 


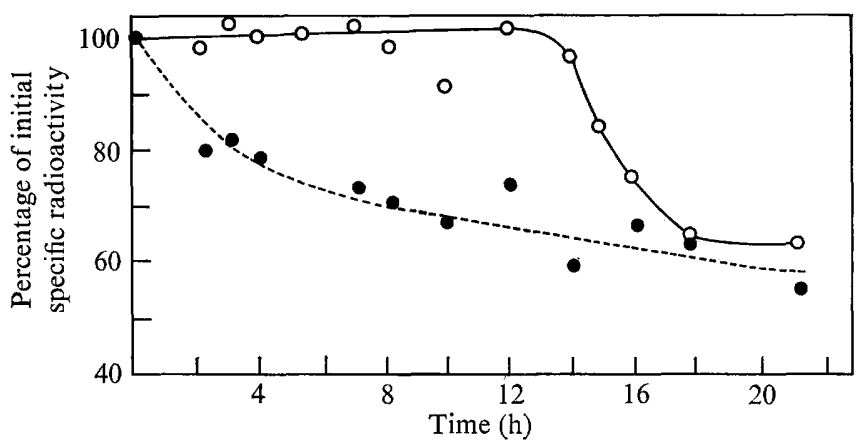

Fig. 4. Turnover of membrane-bound rRNA and free rRNA during development. Cells were labelled with [6- $\left.{ }^{3} \mathrm{H}\right]$ uracil $\left(0 \cdot 3 \mathrm{mCi}, 12 \mathrm{mCi} \mu \mathrm{mol}^{-1}\right)$ during the growth phase in $\mathrm{HL}-5$ medium for two generations ( 20 to $24 \mathrm{~h}$ ). Radioactivity was chased during morphological development by placing labelled amoebae on Millipore filters saturated with LP solution containing $10^{-3} \mathrm{M}$ unlabelled uracil. RNAs from membrane-bound and free ribosomes were isolated and the relative specific radioactivities (as percentages of the initial values) of these two types of rRNA were determined at various times after placing the cells on the filters. The specific radioactivity of rRNA was measured as the trichloroacetic acid-insoluble radioactivity (c.p.m.) per mg RNA or protein. $\mathrm{O}-\mathrm{O}$, Membrane-bound rRNA; --- , free rRNA. Each point represents the average value of at least three experiments.

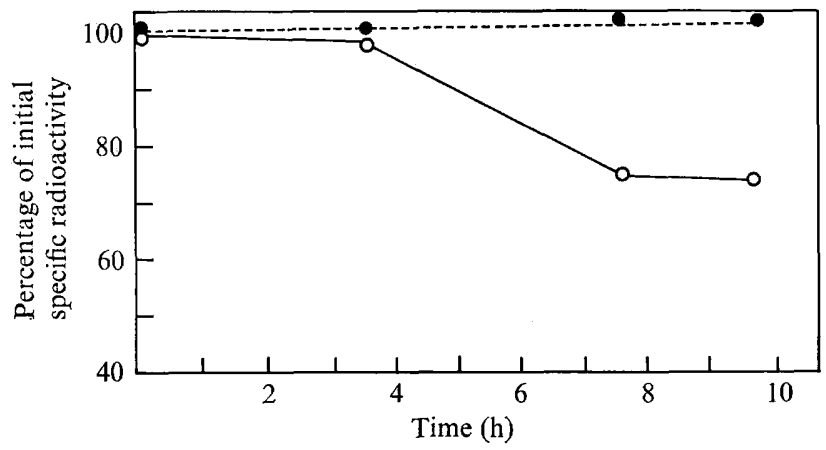

Fig. 5. Turnover of membrane-bound rRNA and free rRNA during disaggregation and reaggregation of pseudoplasmodia. Developmental aggregates were labelled with $\left[6-{ }^{3} \mathrm{H}\right]$ uracil $(0 \cdot 3 \mathrm{mCi}$, $12 \mathrm{mCi} \mu \mathrm{mol}^{-1}$ ) after 8 to $10 \mathrm{~h}$ incubation on a filter. Labelled aggregates were dissociated into unicellular amoebae (see Methods) and then placed back on filters saturated with LP solution containing $10^{-3} \mathrm{M}$ unlabelled uracil during the reaggregation processes. RNAs from membranebound and free ribosomes were isolated and their relative specific radioactivities were determined as described in the legend to Fig. 4. $\bigcirc-\bigcirc$, Membrane-bound rRNA; --- - , free rRNA. Development after reaggregation occurs more rapidly than during normal development so that the points at $3.75,7.75$ and $9.75 \mathrm{~h}$ were developmentally equivalent to $8 \mathrm{~h}$ (early aggregation), $14 \mathrm{~h}$ (late aggregation, nipple formation) and $16 \mathrm{~h}$ (transition to pseudoplasmodium) stages (Newell, Telser \& Sussman, 1969), respectively.

AMP, 0.600; CMP, 0.707; GMP, 0.514; UMP, 0.877) and absorption maxima in acid conditions (AMP, $257 \mathrm{~nm}$; CMP, $280 \mathrm{~nm}$; GMP, $256 \mathrm{~nm}$; UMP, $261 \mathrm{~nm}$ ). An additional faint spot observed on the chromatographs may have been one of the minor nucleotides (e.g. pseudo-UMP). The molar concentration of each major nucleotide was calculated from its absorbance. Both membrane-bound rRNA and free rRNA had relatively low $\mathrm{G}+\mathrm{C}$ contents and there was no significant difference in the $\% \mathrm{GC}$ between these two classes of rRNAs throughout growth and development. 


\section{Relative amounts of RNA from membrane-bound and free ribosomes throughout development}

Although there was little evidence of qualitative differences between the structure of RNA from membrane-bound and free ribosomes in $D$. discoideum, it was still important to determine whether there was any quantitative modulation of RNA from the membranebound and free ribosomes throughout the developmental processes. When rRNAs from the two classes of ribosomes were isolated at various times after amoebae had been placed on Millipore filters, membrane-bound rRNA was found to represent 13 to $16 \%$ of the total cellular rRNA. This value remained constant throughout development.

\section{Turnover of RNA from membrane-bound ribosomes during morphogenesis}

Cocucci \& Sussman (1970) have shown that RNA from free ribosomes turns over rapidly in the stationary period before the onset of development. Our data (Fig. 4) confirm the previous results for free ribosomes and show that, in contrast, the RNA from membranebound ribosomes did not turn over during stationary phase but turned over rapidly shortly after aggregation.

\section{Turnover of RNA from membrane-bound and free ribosomes during disaggregation and reaggregation of pseudoplasmodia}

During slime mould morphogenesis, the highly differentiated pseudoplasmodia can be dissociated into unicellular amoebae by chemical and mechanical techniques (Sussman, 1951). These dissociated cells reaggregate very rapidly within a few hours and recapitulate morphogenesis by forming normal fruiting bodies. Since membrane-bound and free rRNAs showed very different turnover patterns during morphogenesis (Fig. 4), the turnover patterns for RNA from membrane-bound and free ribosomes during disaggregation and reaggregation were measured. The data (Fig. 5) showed that the RNA from free ribosomes made previously in aggregating pseudoplasmodia did not turn over at all during the disaggregation and reaggregation processes. The RNA from membrane-bound ribosomes synthesized initially during the aggregation period also did not turn over in the recapitulation period (first 2 to $3 \mathrm{~h}$ on filters) but turned over rapidly after 3 to $4 \mathrm{~h}$ of reaggregation.

\section{DISCUSSION}

Although electron microscopic studies by Maeda \& Takeuchi (1969) have shown that $D$. discoideum contains ribosomes bound to endoplasmic reticulum, such ribosomes have never been isolated. We have isolated and characterized RNA from membrane-bound ribosomes from the cellular slime mould. These ribosomes were obtained by centrifuging cell-free extracts of $D$. discoideum at $17300 \mathrm{~g}$; the pellet so obtained also contained various membranous materials including rough endoplasmic reticulum, mitochondrial inner and outer membranes, possibly some plasma membranes and smooth endoplasmic reticulum. With most organisms or tissues, it is difficult to separate a pure rough ER fraction. Membrane-bound ribosomes of $D$. discoideum could have been associated with either endoplasmic reticulum or mitochondrial membranes. Electron microscopic examination of the preparations suggested that ER comprised the majority of membranes present. No contamination with other RNA such as that which might derive from mitochondria was evident.

The membrane-bound and free ribosomal RNAs were similar in structure. Their sizes, as measured by sedimentation rates in sucrose gradients, were approximately the same. The $\mathrm{G}+\mathrm{C}$ contents were relatively low in RNAs from both membrane-bound and free ribosomes. The only difference found between these two classes of rRNAs was with respect to their extent of methylation. The 25S RNA from the membrane-bound ribosomes appears 
to be less methylated than 25S RNA from the free ribosomes. There seems to be no difference in methylation, however, between the 17S RNAs from membrane-bound and free ribosomes. The difference in the 25S RNAs, if significant, may reflect possible functional differences between the RNAs of free and membrane-bound ribosomes. Differences in methylation between RNAs from membrane-bound and free ribosomes have previously been described by Murthy (1972) but he found that the RNAs from membrane-bound ribosomes had more methyl groups than the corresponding RNAs from free ribosomes.

Throughout the developmental stages, the RNA from membrane-bound ribosomes represented a relatively constant proportion (13 to $16 \%$ ) of the total cellular rRNA. Development in $D$. discoideum therefore does not involve changes in the fraction of membrane-bound ribosomes.

During morphogenesis of $D$. discoideum there is a net loss of total RNA per cell. If this were caused only by the breakdown of growth stage (old) rRNAs during morphogenesis, the specific radioactivity of the rRNAs labelled during the growth stage should remain at its original level. If new rRNAs were being synthesized, the specific radioactivity would be expected to decrease.

We have shown that the membrane-bound rRNA is turned over during development but that the temporal turnover pattern of this rRNA was very different from that of the free rRNA. Whereas the free rRNA turned over during the stationary phase preceding aggregation, the membrane-bound rRNA was quite stable until late in the development when turnover commenced. Free rRNAs previously made in aggregating pseudoplasmodia did not turn over at all during disaggregation and reaggregation of pseudoplasmodia, whereas RNA from membrane-bound ribosomes, which did not turn over during early reaggregation stage, turned over rapidly in the late reaggregation phase. The turnover studies in this report could involve degradation/synthesis and/or possible exchange of ribosomes between bound and free states. At present, our techniques are not able to distinguish between these two possibilities. Nevertheless, the differential rates of turnover of RNA from membrane-bound and free ribosomes throughout the morphogenic cycle of $D$. discoideum might indicate a requirement for ribosomal structural changes during various functional states.

This investigation was supported by NIH research grant number GM-18476 from the Institute of General Medical Sciences.

\section{REFERENCES}

AtTARdi, B. \& AtTARdi, G. (1967). A membraneassociated RNA of cytoplasmic origin in HeLa cells. Proceedings of the National Academy of Sciences of the United States of America 58, 1051-1058.

AtTARdi, B. \& AtTARdi, G. (1969). Sedimentation properties of RNA species homologous to mitochondrial DNA in HeLa cells. Nature, London 224, 1079-1083.

Attardi, B., Craviot, B. \& Attardi, G. (1969). Membrane-bound ribosomes in $\mathrm{HeLa}$ cells. I. Their proportion to total cell ribosomes and their association with messenger RNA. Journal of Molecular Biology 44, 47-70.

Bonner, J. T. (1967). The Cellular Slime Molds, 2nd edn. Princeton, U.S.A.: Princeton University Press.

Ceccarini, C. \& Maggio, R. (1968). Studies on the ribosomes from the cellular slime molds, Dictyostelium discoideum and Dictyostelium purpureum. Biochimica et biophysica acta 166, 134141.
Cocucci, S. M. \& Sussman, M. (1970). RNA in cytoplasmic and nuclear fractions of cellular slime mold amebas. Journal of Cell Biology 45, 399-407.

Hulse, J. L. \& WetTstein, F. O. (1972). Two separable cytoplasmic pools of native ribosomal subunits in chick embryo tissue culture cells. Biochimica et biophysica acta 269, 265-275.

Leboy, P. S., Cox, E. C. \& Flaks, J. G. (1964). The chromosomal site specifying a ribosomal protein in E. coli. Proceedings of the National Academy of Sciences of the United States of America 52, 1367-1374.

Looms, W. (1975). Dictyostelium discoideum: $A$ Developmental System. New York: Academic Press.

Maeda, Y. \& Takeuchi, I. (1969). Cell differentiation and fine structures in the development of the cellular slime molds. Development, Growth and Differentiation 11, 232-245. 
Murthy, M. E. V. (1972). Free and membranebound ribosomes of rat cerebral cortex. Journal of Biological Chemistry 247, 1944-1950.

Newell, P. C., Telser, A. \& Sussman, M. (1969). Alternative developmental pathways determined by environmental conditions in the cellular slime mold Dictyostelium discoideum. Journal of Bacteriology 100, 763-768.

RoumaintzefF, M., Summers, D. F. \& Maizel, J. V. (1971). In vitro protein synthetic activity of membrane-bound poliovirus polysomes. Virology 44, 24.9-258.

RuSHIZKY, G. W. \& Sober, H. A. (1963). Studies on the specificity of ribonuclease $\mathbf{T}_{2}$. Journal of Biological Chemistry 238, 371-376.

Sabatini, D., Tashiro, Y. \& Palade, G. (1966). On the attachment of ribosomes to microsomal membrane. Journal of Molecular Biology 19, 503524.

Sussman, M. (1951). The origin of cellular heterogeneity in the slime molds, Dictyosteliaceae. Journal of Experimental Zoology 118, 407-418.
Sussman, M. (1966). Biochemical and genetic methods in the study of cellular slime mold development. Methods in Cell Physiology 2, 397 410.

Sussman, M. \& Sussman, R. (1969). Patterns of RNA synthesis and of enzyme accumulation and disappearance during cellular slime mould cytodifferentiation. Symposia of the Society of General Microbiology 19, 403-435.

TAKAGI, M. \& OGATA, K. (1968). Direct evidence for albumin biosynthesis by membrane-bound polysomes in rat liver. Biochemical and Biophysical Research Communications 33, 55-60.

Takagi, M., Tanaka, T. \& Ogata, K. (1969). Evidence for exclusive biosynthesis in vivo of serum albumin by bound polysomes of rat liver. Journal of Biochemistry 65, 651-653.

Tamm, C., Shapiro, H. S., Lipshitz, R. \& ChargafF, E. (1953). Distribution density of nucleotides within a deoxyribonucleic acid chain. Journal of Biological Chemistry 203, 673-688.

WyatT, G. R. (1951). The purine and pyrimidine composition of deoxypentose nucleic acids. Biochemical Journal 48, 584-590. 